\title{
Transcortin: A Corticosteroid-binding Protein of Plasma. VII. Half-Life in Normal and Estrogen-treated Subjects *
}

\author{
Avery A. Sandberg, M. Woodruff, H. Rosenthal, S. Nienhouse, and \\ W. R. Slaunwhite, Jr. \\ (From the Roswell Park Memorial Institute, Buffalo, N. Y.)
}

In 1959 we described elevated plasma concentrations of transcortin during pregnancy and after the administration of estrogens $(1,2)$. Since then, a number of investigations utilizing a variety of methodologies to ascertain the binding of cortisol to transcortin have confirmed our observations $(3-8)$. The different techniques used and the diverse arithmetic approaches employed all indicate that the plasma concentration of transcortin rises about threefold during pregnancy or after estrogen therapy. These findings (3-8) are in essential agreement with our original, less sophisticated observations and calculations. An important contribution has been the isolation by Seal and Doe $(9,10)$ of a highly purified plasma transcortin preparation, making it possible to ascertain the amino acid composition of the protein and many of its physical properties. They have shown that transcortin has one binding site for cortisol and a molecular weight of approximately $45,000(9,10)$. More recently, these workers have demonstrated, by means of isolation studies, that the plasma transcortin concentration is approximately $2.5 \mathrm{mg}$ per $100 \mathrm{ml}$ in normal subjects and $7.5 \mathrm{mg}$ per $100 \mathrm{ml}$ in estrogen-treated subjects (7). These and other values for normal, estrogen-treated, and pregnant subjects (3-8) are higher than our original calculations (1). Our low values can be attributed to the crudeness of the early techniques and the less critical theoretical physicochemical approaches utilized. The methods used in our laboratory now obviate these shortcomings and yield values similar to those obtained by other workers.

\footnotetext{
* Submitted for publication September 19, 1963 ; accepted November 14, 1963.

This study has been supported in part by grant A-1240 from the National Institute of Metabolic and Endocrine Disorders, U. S. Public Health Service.
}

The present study was undertaken to determine whether the elevated transcortin levels following estrogen therapy are due 1) to increased synthesis of the protein or 2) to decreased turnover and, hence, prolonged half-life of transcortin.

This study has been made feasible through the isolation by Seal and Doe $(9,10)$ of a highly purified and well-characterized preparation of transcortin, making possible the injection of labeled transcortin free from any significant protein contaminants. Another important advance that encouraged us to undertake the study has been the feasibility of utilizing labeled proteins in the study of their half-lives and the demonstration that the introduction of a small number of iodine atoms into a protein appears not to change its biological behavior (11-15).

\section{Materials and Methods}

The transcortin used in this study was isolated according to the method of Seal and Doe $(9,10) .^{1}$ The protein was iodinated according to the technique of Pressman and Eisen (16) as modified by Day, Planinsek, Korngold, and Pressman (17). The iodination procedures described below were standardized many times in our laboratory utilizing various proteins (17). The iodination of the transcortin was carried out on the morning when the subjects were injected. Since we did not know the length of time during which the plasma would have to be sampled, $\mathrm{I}^{125}$ was chosen because its half-life is greater than that of $I^{131}$. The results indicate that $\mathrm{I}^{131}$ could have served as well.

The iodide in $266 \mu \mathrm{c}$ of $\mathrm{KI}^{125}$ (carrier free) and 80 $\mu 1$ of $0.0025 \mathrm{M}$ KI was oxidized by the addition of 0.1 $\mathrm{ml}$ of $1 \mathrm{~N} \mathrm{HCl}$ and $0.05 \mathrm{ml}$ of $0.02 \mathrm{M} \mathrm{NaNO}$. The $\mathrm{pH}$ was immediately made slightly alkaline by adding $0.5 \mathrm{ml}$ of a $1: 4$ (vol/vol) mixture of $1 \mathrm{~N} \mathrm{NaOH}$ and $0.167 \mathrm{M}$ borate buffer ( $\mathrm{pH} 7.9$ ) in $0.133 \mathrm{M} \mathrm{NaCl}$. The alkaline iodine solution was added to $3.0 \mathrm{mg}$ of transcortin dissolved in $0.6 \mathrm{ml}$ of water. The reaction mix-

1 The transcortin was kindly supplied by Dr. U. S. Seal. 
ture was immediately passed through a $4-\times 40-\mathrm{mm}$ column of Amberlite IR-4B (OH) anion exchange resin (analytical grade) to remove iodide ion. At this step, $22 \%$ of the $\mathrm{I}^{125}$ reacted with transcortin. After passage through another column of IR-4B resin to ensure complete removal of iodide, the iodination yield was $16 \%$, which was equivalent to 0.4 atoms of iodine per mole of transcortin. This solution was diluted to $250 \mathrm{ml}$ with physiological saline.

Treatment of two patients with carcinoma of the prostate with diethylstilbestrol (15 $\mathrm{mg}$ per day) was initiated 2 weeks before the injection of $\mathrm{I}^{125}$-transcortin and continued throughout the experimental period. Three male laboratory personnel served as untreated controls. Just before the injection of $\mathrm{I}^{125}$-transcortin, $30 \mathrm{ml}$ of blood was drawn in heparin. The saline solution of $\mathrm{I}^{123}$-transcortin $(50 \mathrm{ml})$ was injected intravenously over a period of 1 to 3 minutes. At periodic intervals small $(10-\mathrm{ml})$ samples of blood from an opposite arm vein were withdrawn for assay of radioactivity. At 1 hour and at 9 days after injection, 50-ml samples of blood were drawn, and chromatography of the plasma from these samples was performed.

Determination of transcortin concentration. Plasma cortisol determinations were performed according to the method of Plager, Cushman, and Chase (18) on the preinjection sample of plasma. Equilibrium dialyses were performed at various concentrations of cortisol as previously described (1), both before and after heating at $60^{\circ}$ for 20 minutes (4). The protein concentration was determined with a Scatchard type plot (19), plotting the ratio of the percentage of unbound versus the concentration of bound cortisol. Our experience (1), as well as that of others $(5,10)$, has shown that the equilibrium constant of association does not change with estrogen stimulation, that is, estrogen stimulation produces more transcortin rather than a different protein. Our data, after subtraction of albumin binding of cortisol, yield a value of $1 \times 10^{-9} \mathrm{M}^{-1}$ for the equilibrium constant of association. Using this value, and a molecular weight of 45,000 for the corticosteroidbinding protein, the concentration of transcortin binding sites was calculated for each plasma. Since Seal and Doe $(9,10)$ have shown that there is only one binding site on transcortin for cortisol, this value is also the concentration of transcortin.

Determination of the half-life of transcortin. From each specimen, 1 or $2 \mathrm{ml}$ of whole blood was removed for counting. The remainder was centrifuged and the volume of plasma and erythrocytes measured. The erythrocytes were washed three times with saline, and 1 or $2 \mathrm{ml}$ of plasma and of washed erythrocytes was assayed for radioactivity in a well-type scintillation counter using a 2 -inch crystal and a spectrometer. The efficiency of counting was $11.3 \%$.

Evidence of identity of $\Gamma^{225}$-transcortin with endogenous transcortin. Selected samples of plasma were chromatographed (for details, see below) on the anionexchange resin, diethylaminoethyl cellulose (DEAEC). $C^{14}$-cortisol was added to each specimen to label the en- dogenous transcortin. Radioactive iodine and carbon were assayed simultaneously in a dual channel liquid scintillation spectrometer in a dioxane-ethoxyethanol solvent (20). The degree of correlation of the two isotopes was taken as a measure of the identity of exogenous $\mathrm{I}^{125}$-transcortin with the endogenous protein.

The chromatography was performed at $4^{\circ}$ as follows. Approximately $30 \mathrm{ml}$ of plasma was dialyzed overnight against 10 vol of distilled water. The $\mathrm{pH}$ of the plasma was adjusted to 5.0, and the plasma was centrifuged. The supernatant liquid was applied to a $2-\times 30-\mathrm{cm}$ column of DEAEC equilibrated with buffer, which was $0.025 \mathrm{M}$ in $\mathrm{NaCl}$ and $0.015 \mathrm{M}$ in $\mathrm{NaH}_{2} \mathrm{PO}_{4}$ at $\mathrm{pH}$ 5.0. After the plasma had percolated into the resin, $0.1 \mu \mathrm{c}$ of 4-C $\mathrm{C}^{14}$-cortisol ( $70 \mu \mathrm{c}$ per $\mathrm{mg}$ ) in buffer was added. Elution with the same buffer was commenced and continued until the optical density at $280 \mathrm{~m} \mu$ of the effluent was between 0.2 and 0.6 . At this point most of the albumin and its associated yellow pigment had been eluted, but the blue band due to ceruloplasmin was at the top of the column. A gradient in ionic strength at a constant $\mathrm{pH}$ of 5.0 was started, using $800 \mathrm{ml}$ of the initial buffer in a mixing chamber and dropping into it a buffer consisting of $1: 9$ ( $\mathrm{vol} / \mathrm{vol}) \quad 0.2 \mathrm{M} \mathrm{NaH} \mathrm{PO}_{4}: 0.09 \mathrm{M}$ $\mathrm{NaCl}$ at $\mathrm{pH} 5.0$. Fractions of $30 \mathrm{ml}$ in volume were collected at a flow rate of less than $1 \mathrm{ml}$ per minute until the blue band had passed out of the column.

The protein concentration of each fraction was determined by comparison with an ovalbumin standard using the absorption band at $280 \mathrm{~m} \mu$. The amount of $\mathrm{I}^{125}$ and $\mathrm{C}^{14}$ in $1 \mathrm{ml}$ of every other fraction was determined in a dual channel liquid scintillation spectrometer. The high voltage and discriminator were set so that $90 \%$ of the $\mathrm{I}^{125}$ counts appeared in the lower channel and $42.5 \%$ in the upper channel. Under these conditions the efficiency of counting (using both channels) of $\mathrm{I}^{125}$ was $78 \%$; that of $\mathrm{C}^{14}$ was $86 \%$. Binding of $\mathrm{C}^{14}$-cortisol was performed by equilibrium dialysis (1) on a suitably diluted sample so that the percentage bound fell between 40 and 60 . The percentage bound per milligram of protein was then calculated. Unless all determinations are brought to the same end-point (not necessarily this one), comparisons are invalid (19).

\section{Results}

All the subjects were injected between 10 a.m. and 12 noon and (except normal subject R.E.) were in fasting condition. In each case the $50 \mathrm{ml}$ of solution containing the $\mathrm{I}^{125}$-labeled transcortin was injected intravenously into an antecubital vein over a period of 2 to 3 minutes, care being taken to insure that no extravascular extravasation of the material occurred. The clearance of the plasma was followed for 15 days. In Figure 1 are shown the clearances of the labeled transcortin from the plasma of the subjects studied. Extrapolation of the slower clearance curve to zero 


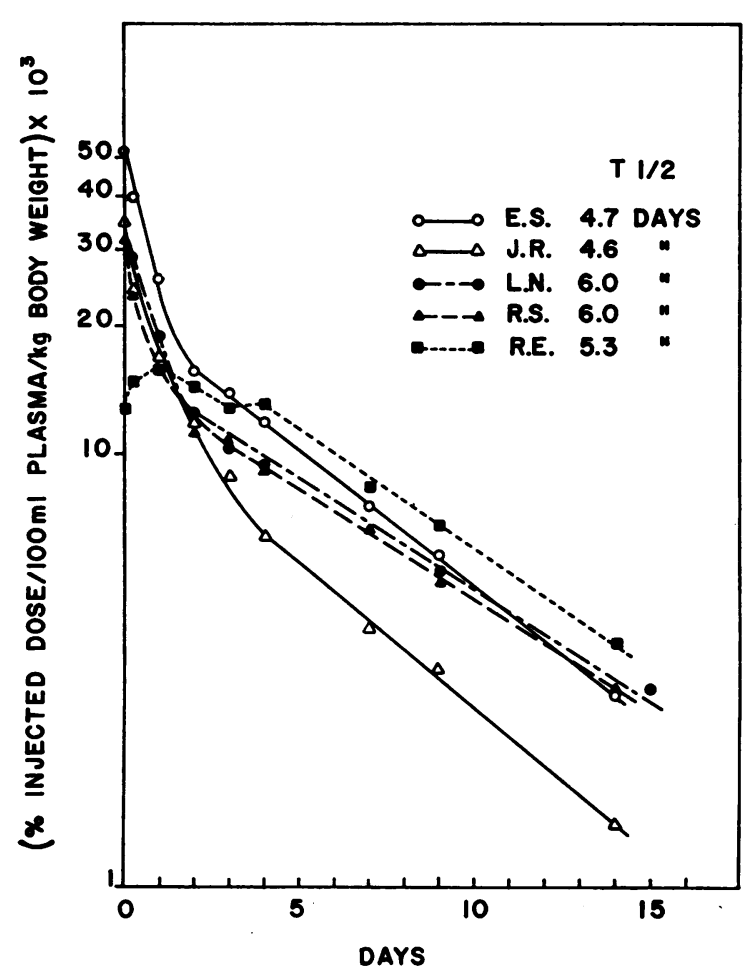

Fig. 1. Clearance of $\mathrm{I}^{125}$-LABEled transcortin From the plasmas of 3 NORMal slbjects (L.N., R.S., AND R.E.) AND 2 ESTROGEN-TREATED PATIENTS WiTh CANCER OF THE PROSTATE (E.S., J.R.). In normal subject R.E., the radioactivity in the plasma rose for 2 days and then decreased similarly to that in the other subjects studied. This may be the result of extravascular leakage of the labeled protein, although at the time of injection no evidence could be found to indicate that the material had not been injected intravenously.

time allows the determination of half-lives of transcortin in the plasma of the subjects. These half-lives range from 4.7 to 6.0 days.

The amount of radioactivity associated with the erythrocytes was negligible in the blood sam-

TABLE I

Plasma cortisol and transcortin concentrations in estrogen-treated and normal subjects

\begin{tabular}{llccc}
\hline \hline Subject & \multicolumn{1}{c}{ Diagnosis } & Wt & Cortisol & $\begin{array}{c}\text { Trans- } \\
\text { cortin* }\end{array}$ \\
\hline & & $k g$ & $\mu g / 100 \mathrm{ml}$ & $\mu M \dagger$ \\
E.S. & Prostate carcinoma & 57 & 44 & 2.23 \\
J.R. & Prostate carcinoma & 82 & 51 & 2.85 \\
L.N. & Normal & 82 & 13 & 0.70 \\
R.S. & Normal & 86 & 7 & 0.77 \\
R.E. & Normal & 69 & 21 & 0.99 \\
\hline
\end{tabular}

${ }^{*} \mathrm{~K}$ was $1 \times 10^{-9} \mathrm{M}^{-1}$ for all subjects.

$\dagger$ Concentration in undiluted plasma. ples obtained during the first postinjection day, and no measurable radioactivity was associated with the red blood cells after that day.

Normal subject R. S. and patient J.R. had their thyroid areas monitored by special equipment 24 hours after injection. Only negligible activity was detected.

In Table I are shown the cortisol and transcortin concentrations in the plasmas of the two estrogen-treated subjects with cancer of the prostate and the values in the three normal subjects. The cortisol values are greatly elevated in the cancer patients. Normal subject R.E. had a cortisol value $(21 \mu \mathrm{g}$ per $100 \mathrm{ml})$ at the upper limit for normal subjects, but he was postprandial. The transcortin concentrations are greatly elevated in the cancer subjects treated with diethylstilbestrol, being $10 \mathrm{mg}$ per $100 \mathrm{ml}(2.23 \mu \mathrm{M})$ and $12.6 \mathrm{mg}$ per $100 \mathrm{ml}(2.85 \mu \mathrm{M})$ for subjects E.S. and J.R., respectively, which agrees with previously published values in similarly treated patients (4-8). The transcortin values in the normal subjects (average, $3.7 \mathrm{mg}$ per $100 \mathrm{ml}$ or $0.82 \mu \mathrm{M})$ are also in agreement with values published in the past (3-8).

Studies on the stability and nature of the transcortin injected were performed by adding a small part of the iodinated transcortin to plasma from one of the estrogen-treated subjects and processing through the chromatography procedure described above. In addition, plasma samples obtained 1 hour and 5 days after injection of the labeled transcortin were processed similarly. In these latter samples no exogenous iodinated transcortin was added; the radioactivity followed was that of the injected protein.

The coincidence of the $\mathrm{I}^{125}$ and $\mathrm{C}^{14}$ peaks in Figure 2 is taken as presumptive evidence of identity of the iodinated transcortin and endogenous transcortin. Since qualitatively the same pattern existed at 1 hour and 5 days after injection, these chromatograms are not shown. No other areas of $\mathrm{I}^{125}$ radioactivity emerged from the column, but because of instrumental aberrations the precise recovery of radioactivity cannot be stated.

That the binding activity shows a peak in a different area is very interesting. At the present time we cannot say whether this represents a single cortisol-binding protein that is most pure on the traiting edge of the protein peak or 


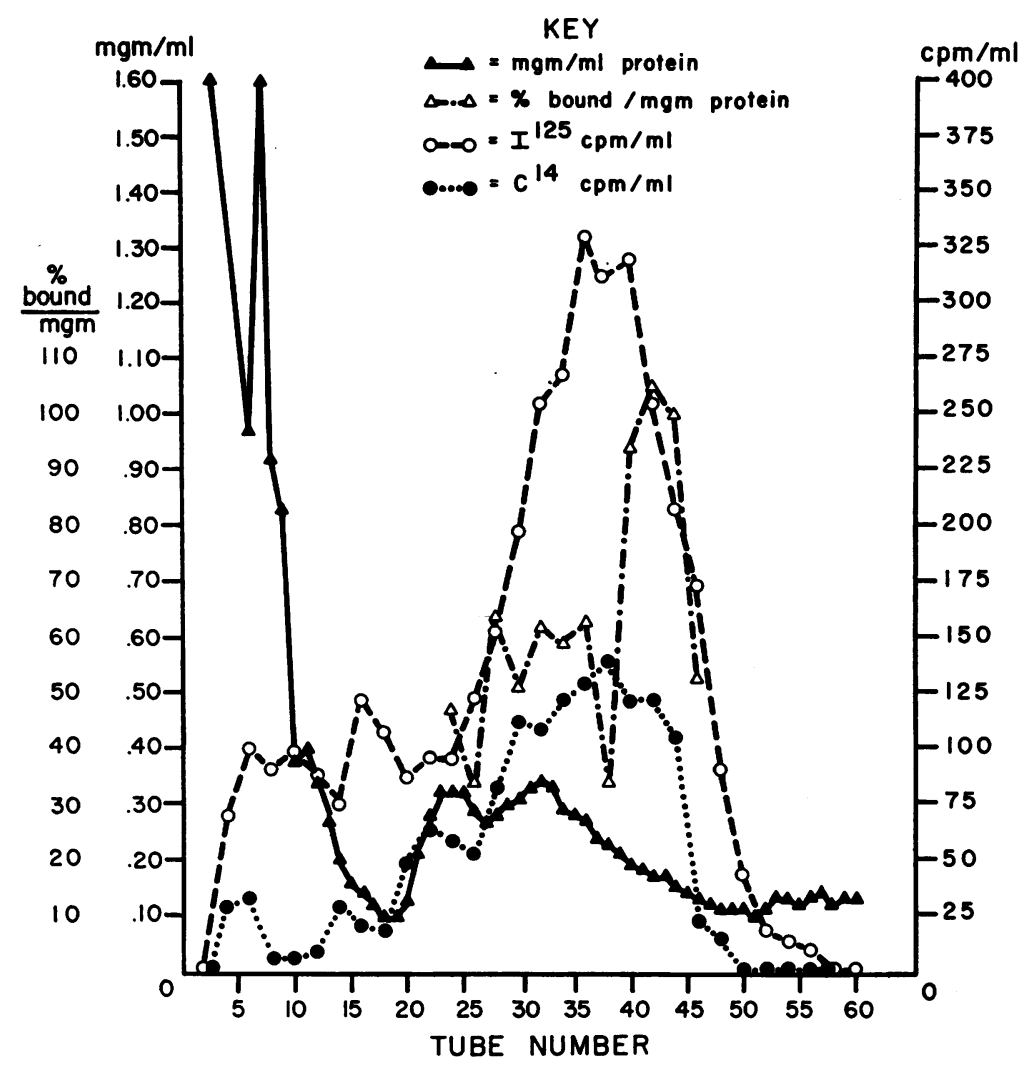

Fig. 2. Graphic Representation of the results after chromatogRAPHY OF PLASMA FOR THE PURIFICATION, IDENTIFICATION, AND LOCALIZATION OF TRANSCORTIN. The figure depicts the protein concentration, cortisolbinding, and distribution of $\mathrm{I}^{125}$-labeled transcortin and added $\mathrm{C}^{\mathbf{1 4}}$-cortisol exhibited by the fractions collected.

whether there are two transcortins involved. This is, however, a consistent finding in all plasmas processed to date in our laboratory. This result does not conflict with those of Seal and Doe $(9,10)$, since they did not routinely do binding determinations as we did. The exchange resin may also be imputed. A change in the physical characteristics of transcortin may occur on the IR-4B ( $\mathrm{OH})$ column, thus accounting for the results shown in Figure 2. Another explanation may be related to the association of cortisol with transcortin. The second smaller peak may represent transcortin free of cortisol, either as a result of the chromatography or unsaturation of the transcortin with cortisol, which then behaves differently on the DEAEC column as compared to transcortin associated with cortisol. We should state, parenthetically, that similar results, i.e., a double peak of binding with a single peak of association of $\mathrm{C}^{\mathbf{1 4}}$-cortisol, with transcortin have been observed in many plasmas, both from normal and estrogen-treated subjects, processed in our laboratory.

\section{Discussion}

There is considerable evidence in the literature that iodination of a protein to a small extent does not change its properties. The behavior of plasma proteins, labeled with a small amount of iodine ${ }^{131}$, in the circulation of animals has been shown to correspond with that of the same proteins biosynthetically labeled with $\mathrm{C}^{14}(12,13)$. Moreover, the specific activity of $\mathrm{I}^{131}$-albumin (0.8 atom iodine per mole) injected into two analbuminemic subjects did not change over a period of 7 weeks (14). De Zoeten and Havinga, in an elegant study, have investigated the kinetics of iodination of the tyrosyl residues in insulin (21, 
22) and have shown that the introduction of 0.8 atom of iodine per mole does not significantly change its biological effectiveness (15). Although we have no experimental evidence that transcortin behaves similarly, the assumption that it does so seems reasonable.

Based on present knowledge, the total plasma pool of transcortin is approximately $75 \mathrm{mg}$ and $225 \mathrm{mg}$ in normal and estrogen-treated subjects, respectively. Since each of the subjects in the present study was injected with less than $1 \mathrm{mg}$ of transcortin, the total plasma pool of this protein was not changed significantly, and the results should reflect the turnover rate of the endogenous transcortin. From the data presented, the halflife of the transcortin pool is 6 days or less in the three normal subjects studied and less than 5 days in the two estrogen-treated subjects. Thus, it appears that the elevated transcortin concentrations induced by estrogen administration cannot be ascribed to slower turnover of the cortisolbinding protein. The increased concentration of transcortin is most likely due to increased synthesis of the protein as a result of the estrogen administered.

In four of the subjects the clearance of the $\mathrm{I}^{125}$-labeled protein from the plasma had an initial steeper rate followed by the slower rate of clearance after 1 to 2 days. This is not uncommon with other injected labeled proteins (14) and other substances. Whether this initial rapid clearance is due to equilibration of the labeled protein with a nonplasma pool or to clearance of nontranscortin $\mathrm{I}^{125}$ is difficult to state. That the clearance may be due to the former rather than the latter is indicated by our inability to find any significant radioactivity over the thyroid area in two of the subjects studied.

Extrapolation of the clearance curves of the $\mathrm{I}^{125}$-labeled transcortin to zero time indicated that, on the average, approximately $50 \%$ of the injected protein was in the plasma pool. The remaining $50 \%$ of the labeled transcortin may have left the plasma through the egress of the protein from the blood into an extravascular pool, or through rapid clearance of nontranscortin-labeled protein. The latter seems unlikely in view of the high purity of the preparation used. That an extravascular pool of transcortin may exist is pointed to by the demonstration of this protein in lymph fluid, joint fluids, and possibly in tissues. The binding of cortisol by tissues has been reported by Levin, Daughaday, and Bremer (23).

In a previous study we reported that transcortin levels which have been elevated by the administration of estrogen have returned to the pretreatment levels within 7 to 10 days after cessation of therapy (24). These findings are in close agreement with the results reported in the present paper. The elevated transcortin levels in pregnant women returned to normal postpartum (24) within the time limits indicated by both studies referred to above.

\section{Summary}

$\mathrm{I}^{125}$-labeled transcortin has been injected intravenously into two estrogen-treated patients with carcinoma of the prostate and three normal subjects. The clearance from the plasma indicated a half-life of approximately five days in the subjects studied. No difference was demonstrated in the clearance of transcortin between the normal subjects and the estrogen-treated subjects. On the basis of the experiments presented, the elevated transcortin levels induced by estrogen are apparently due to increased synthesis of the protein.

\section{Acknowledgments}

We wish to thank Mrs. Anne Agacz, Miss Joyce Romano, and Mr. Elek Karsay for valuable technical assistance. We are grateful to Dr. Oliver Roholt of Roswell Park Memorial Institute for advice regarding the process of iodination of proteins.

\section{References}

1. Slaunwhite, W. R., Jr., and A. A. Sandberg. Transcortin : a corticosteroid-binding protein of plasma. J. clin. Invest. 1959, 38, 384.

2. Sandberg, A. A., and W. R. Slaunwhite, Jr. Transcortin: a corticosteroid-binding protein of plasma. II. Levels in various conditions and the effects of estrogens. J. clin. Invest. 1959, 38, 1290.

3. Booth, M., P. F. Dixon, C. H. Gray, J. M. Greenaway, and N. J. Holness. Protein binding of cortisol in health and in pregnancy. J. Endocr. 1961, 23, 25.

4. Daughaday, W. H., R. E. Adler, I. K. Mariz, and D. C. Rasinski. Measurement of the binding capacity of corticosteroid-binding globulin in human plasma. J. clin. Endocr. 1962, 22, 704. 
5. Mills, I. H. Transport and metabolism of steroids. Brit. med. Bull. 1962, 18, 127.

6. De Moor, P., K. Heirwegh, J. F. Heremans, and M. Declerck-Raskin. Protein binding of corticoids studied by gel filtration. J. clin. Invest. 1962, 41, 816.

7. Doe, R. P., and U. S. Seal. Protein binding of cortisol in man (abstract). J. clin. Invest. 1963, 42, 929.

8. Murphy, B. P., and C. J. Pattee. A study of the binding capacity of corticosteroid-binding globulin in plasma. J. clin. Endocr. 1963, 23, 459.

9. Seal, U. S., and R. P. Doe. Purification and properties of transcortin, the cortisol-binding globulin from patients with cancer of the prostate. Cancer chem. Rep. 1962, no. 16, 329.

10. Seal, U. S., and R. P. Doe. Corticosteroid-binding globulin I. Isolation from plasma of diethylstilbestrol-treated men. J. biol. Chem. 1962, 237, 3136.

11. Sterling, $K$. The turnover rate of serum albumin in man as measured by $\mathrm{I}^{131}$-tagged albumin. J. clin. Invest. 1951, 30, 1228.

12. Campbell, R. M., D. P. Cuthbertson, C. M. Matthews, and A. S. McFarlane. Behaviour of ${ }^{14} \mathrm{C}$ - and ${ }^{131}$ I-labelled plasma proteins in the rat. Int. J. appl. Radiat. 1956, 1, 66.

13. Cohen, S., R. C. Holloway, C. Matthews, and A. S. McFarlane. Distribution and elimination of ${ }^{131} \mathrm{I}-$ and ${ }^{14} \mathrm{C}$-labelled plasma proteins in the rabbit. Biochem. J. 1956, 62, 143.

14. Bennhold, H., and E. Kallee. Comparative studies of the half-life of $\mathrm{I}^{131}$-labeled albumins and nonradioactive human serum albumin in a case of analbuminemia. J. clin. Invest. 1959, 38, 863.

15. De Zoeten, L. W., and R. van Strik. A study of the biological activity of iodinated insulin. Rec. Trav. chim. Pays-Bas 1961, 80, 927.

16. Pressman, D., and H. N. Eisen. The zone of localization of antibodies. V. An attempt to saturate antibody-binding sites in mouse kidney. J. Immunol. 1950, 64, 273.

17. Day, E. D., J. Planinsek, L. Korngold, and D. Pressman. Tumor-localizing antibodies purified from antisera against Murphy rat lymphosarcoma. J. nat. Cancer Inst. 1956, 17, 517.

18. Plager, J. E., P. Cushman, Jr., and A. E. Chase. The plasma cortisol response to ACTH in "idiopathic hirsutism." J. clin. Invest. 1961, 40, 1315.

19. Edsall, J. T., and J. Wyman. Biophysical Chemistry. New York, Academic Press, 1958, vol. 1, pp. 617620.

20. Bruno, G. A., and J. E. Christian. Determination of carbon-14 in aqueous bicarbonate solutions by liquid scintillation counting techniques. Application to biological fluids. Analyt. Chem. 1961, 33, 1216.

21. De Zoeten, L. W., and O. A. de Bruin. The reactivities of the tyrosine residues in insulin with respect to iodine I. Rec. Trav. Chim. Pays-Bas 1961, 80, 907.

22. De Zoeten, L. W., and E. Havinga. The reactivity of the tyrosine residues in insulin with respect to iodine II. Rec. Trav. Chim. Pays-Bas 1961, 80, 917.

23. Levin, M. E., W. H. Daughaday, and R. Bremer. Tissue binding of hydrocortisone. J. Lab. clin. Med. 1955, 45, 833.

24. Sandberg, A. A., W. R. Slaunwhite, Jr., and A. C. Carter. Transcortin: a corticosteroid-binding protein of plasma. III. The effects of various steroids. J. clin. Invest. 1960, 39, 1914. 